\title{
バニリルフルオロンとコバルト（II）を用いる スペルミンの吸光光度定量
}

柏木 翔和 ${ }^{1}$, 柗下もも 小 $^{1}$, 藤获美穂代 ${ }^{1}$, 山口 敬子 ${ }^{* 1}$,

1 緒

言

ポリアミンは, 3 個以上のアミノ基を持つ非タンパク性 の脂肪族アミンの総称で，メチオニンやアルギニンに由来 し，ポリアミン合成経路によりオルニチンからまずプトレ シンが (Put) が生成され, 次いでスペルミジン ( $\mathrm{Spd})$, ス ペルミン（Spm）が作られる，この反応は，オルニチン脱 炭酸䤉素により律速される。 これらポリアミンは, 正電荷 がメチレン鎖 3 のまたは 4 個ごとに配列した塩基性の強い 低分子化合物であり，その物性から， DNA， RNA，リン脂 質などのような負に荷電した高分子物質に結合してそれを 安定化したり, 高分子同士の反応を円滑に進めたり, 逆に 阻害したりする役割や，増殖・分化において重要な働きを 演じていると考えられているが, 分子レベルでのポリアミ ンの役割については, その存在領域の広さと, その作用点 の多さが実証を困難にしている. 生体内では主に, 胸腺, 前立腺, 膵臓などの核酸やタンパク質合成の盛んな組織に 含まれており, 白血病, 悪性リンパ腫, 消化器ガン, 肺ガ ン, 卵巣ガンなど, 多くの局在性のガンで, 特に進行性の 場合には, 尿中排泄量の増加などがみられる. したがって, 臨床上ポリアミンの測定は, 悪性腫瘍診断の補助, 術後化 学療法後の効果判定に有用であり, また, 心筋梗塞, 彩原 病やその他の炎症性疾患でも高值を示し，このような病態 のアセスメントに役立つ可能性が示唆されている ${ }^{1}$.

ポリアミンの定量法としては, 高速液体クロマトグラフ法2) 9) (HPLC: High Performance Liquid Chromatography), 免疫 酵素法 ${ }^{10)}$ (ELIZA: Enzyme Linked Immunosorbent Assay）あ るいはガスクロマトグラフ法 ${ }^{1112)}$ (GC: Gas Chromatography) などが報告されているが, いずれも操作が煩雑で, 選択性, 感度, 経済性などの様々な点において優れた分析法とは言

\footnotetext{
†若手研究者の初論文特集

* E-mail : yamaguti@gly.oups.ac.jp

${ }^{1}$ 大阪薬科大学臨床化学研究室 : 569-1094 大阪府高槻市奈佐原 4-20-1

${ }^{2}$ 大阪信愛女学院 : 536-8585 大阪府大阪市城東区古市 2-7-30

3 サエラ薬局 : 541-0053 大阪府大阪市中央区本町 2-2-5 本町第 2 ビル 3 階
}

宮地加奈子 ${ }^{1}$, 浅野麻実子 ${ }^{1}$, 松村 人志 $^{1}$, 藤田 芳一 $^{1,2,3}$

い難い，一方，ポリアミンが複数の窒素原子を持っている ので, マンガン (II), 銅 (II) , パラジウム (II) など多くの金 属イオンと錯生成されることが知られている ${ }^{13) 14}$ にもかか わらず，その金属配位能を利用した定量法はほとんど報告 されていない ${ }^{15)}$. したがって，今回ポリアミンのうち，生 理化学的, 臨床化学的に最も興味深いSpm を取り上げ, ま た有機試薬として種々の病態関連化合物の分析に応用して いる ${ }^{16)}$ キサンテン系色素の一つであるバニリルフルオロン (VF, Fig. 1)，金属イオンとしてコバルト(II) $\{\mathrm{Co}(\mathrm{II})\}$ を 用いる [金属一有機試薬 $-\mathrm{Spm}$ ］の三元錯体生成反応を利 用する簡便，高感度な吸光光度定量法の確立を目的として 検討した.

$$
2 \text { 実験 }
$$

\section{$2 \cdot 1$ 試 薬}

$2 \cdot 1 \cdot 1$ 色素の合成 文献記載 ${ }^{17)}$ の方法に準拠して, 無水酢酸 $20 \mathrm{~mL}$ と硫酸 $1 \mathrm{~mL}$ の混液に $30 \sim 50{ }^{\circ} \mathrm{C}$ で 1,4 ンゾキノン $10 \mathrm{~g}$ をよく猺䢁しながら加えたのち, 室温で 30 分〜 1 時間放置した. 次いで, $500 \mathrm{~mL}$ の水を加え, 析 出した乳白色沈殿物を十分水洗し, 万過した，得られた白 色沈殿物を $\left(\mathrm{mp} .99 \sim 100{ }^{\circ} \mathrm{C}\right)$ 約 2 時間隇圧乾燥し, 1,2,4ベンゼントリオールトリアセテート（Tri-Ace）を得た.

次に, バニリン $3 \mathrm{~g}$ と Tri-Ace $10 \mathrm{~g}$ を $300 \mathrm{~mL}$ のナスフ ラスコに入れ, $20 \%$ エタノール $100 \mathrm{~mL}$ と濃硫酸 $1 \mathrm{~mL}$ 加えたのち, 混液が濃赤色となるまで 3 時間水浴中で加熱 反応させた，本混液を 3 週間冷暗所に放置したのち，沈殿

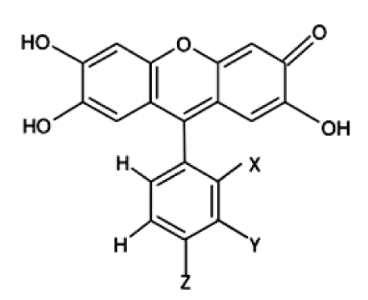

\begin{tabular}{cccc}
\hline dyes & $\mathrm{X}$ & $\mathrm{Y}$ & $\mathrm{Z}$ \\
\hline $\mathrm{VF}$ & $\mathrm{H}$ & $\mathrm{OCH}_{3}$ & $\mathrm{OH}$ \\
$\mathrm{SPF}^{1}$ & $\mathrm{SO}_{3} \mathrm{H}$ & $\mathrm{H}$ & $\mathrm{H}$ \\
$\mathrm{OCPF}^{2}$ & $\mathrm{COOH}$ & $\mathrm{H}$ & $\mathrm{H}$ \\
\hline
\end{tabular}

Fig. 1 Structure of Xanthene dyes

1, o-sufophenylfluorone; 2, o-carboxyphenylfluorone 
した粗 VFをろ取した。

上記の操作で得た粗 VFを，炭酸水素ナトリウムを飽和 させたメタノールに加え, 水浴中で加熱還流して溶解させ たのち，10\% 酢酸中に温時ろ過し，数日間冷暗所に放置 した，生じた再沈殿物をろ取して十分水洗し，VFを得た。 得られた VFを恒量になるまで十分減圧乾燥し, 精製 VF と して使用した（収率 : $11.1 \%$ ） [ ${ }^{1} \mathrm{H}-\mathrm{NMR}: \delta 7.04(\mathrm{~d}, 1 \mathrm{H}, \mathrm{J}=$ $8.05 \mathrm{~Hz}), \delta 7.03(\mathrm{sd}, 1 \mathrm{H}, \mathrm{J}=0.55 \mathrm{~Hz}), \delta 6.86(\mathrm{dd}, 1 \mathrm{H}, \mathrm{J}=8.05$, $1.65 \mathrm{~Hz}), \delta 6.83(\mathrm{~s}, 2 \mathrm{H}), \delta 6.68(\mathrm{~s}, 2 \mathrm{H}), \delta 3.80(\mathrm{~s}, 3 \mathrm{H})]$ [HRMS(FAB): Calcd for $\mathrm{C}_{20} \mathrm{H}_{15} \mathrm{O}_{7}(\mathrm{M}+\mathrm{H}): 367.0818$ Found 367.0821]

OCPF は, 文献記載 ${ }^{17)}$ の方法に準拠して, $p$-ベンゾキノ ンと無水酢酸より生成した, 1, 2, 4-ベンゼントリオールト リアセテートと無水フタル酸をモル比 $2: 1$ の割合で混合 し, $140 \sim 160{ }^{\circ} \mathrm{C}$ ので混合物の色調が黒黄色になるまで加 熱したのち，無水塩化亜鉛を縮合剂として加え，さらに蛍 光性のある赤黒色になるまで加熱を続けた. 放冷後, 反応 物を $5 \%$ 水酸化ナトリウム液で溶解し, 万液に $30 \%$ 酢酸 を加えて, 冷暗所で 3 日間静置後, ろ取して得た粗 OCPF を, $0.5 \%$ 塩酸エタノール溶液中にて加熱還流して溶解さ せたのち, 不溶物をろ取し, 万液濃縮液に少量の水を加え て生成した再沈殿物をふたたびメタノール：エタノール： 水 $(1: 1: 1)$ の混液に溶解したち数日間冷暗所に静置し た. 最後にろ取した赤茶色沈殿物を十分水洗し, 恒量にな るまで減圧乾燥させ精製 OCPF を得た。(収率 $6.6 \%$ )

[ ${ }^{1} \mathrm{H}-\mathrm{NMR}: \delta 9.00 \mathrm{brs}, \delta 8.09 \mathrm{~d}(\mathrm{~d}, 1 \mathrm{H}, \mathrm{J}=7.3 \mathrm{~Hz}), \delta 7.79$ $(1 \mathrm{H}, \mathrm{J}=7.6 \mathrm{~Hz}), \delta 7.71(\mathrm{dd}, 1 \mathrm{H}, \mathrm{J}=8.05,1.65 \mathrm{~Hz}), \delta 6.83$ $(\mathrm{s}, 2 \mathrm{H}), \delta 6.68(\mathrm{~s}, 2 \mathrm{H}), \delta 3.80(\mathrm{~s}, 3 \mathrm{H})$ ] [HRMS(FAB): Calcd for $\mathrm{C}_{20} \mathrm{H}_{15} \mathrm{O}_{7}(\mathrm{M}+\mathrm{H}): 367.0818$ Found 367.0821]

SPF は, 文献記載 ${ }^{17)}$ の方法に準拠して, $p$-ベンゾキノン と無水酶酸より生成した，1，2，4-ベンゼントリオールトリ アセテートとベンズアルデヒドスルホン酸ナトリウムをモ ル比 $2: 1$ の割合で混合し,メタンスルホン酸を縮合剤とし て加え, $20 \%$ エタノール溶液にて内容物が赤褐色になる まで加熱還流したのち, 冷暗所で 3 週間程度静置し, 生成 した沈殿物をろ取し, 水, メタノールを用いて再結晶した。 (収率 $11.1 \%$ )

[ ${ }^{1} \mathrm{H}$-NMR: $\delta 7.04(\mathrm{~d}, 1 \mathrm{H}, \mathrm{J}=8.05 \mathrm{~Hz}), \delta 7.03(\mathrm{sd}, 1 \mathrm{H}, \mathrm{J}=0.55$ $\mathrm{Hz}), \delta 6.86(\mathrm{dd}, 1 \mathrm{H}, \mathrm{J}=8.05,1.65 \mathrm{~Hz}), \delta 6.83(\mathrm{~s}, 2 \mathrm{H}), \delta 6.68$ $(\mathrm{s}, 2 \mathrm{H}), \delta 3.80(\mathrm{~s}, 3 \mathrm{H})$ ] [HRMS(FAB): Calcd for $\mathrm{C}_{20} \mathrm{H}_{15} \mathrm{O}_{7}$ $(\mathrm{M}+\mathrm{H}): 367.0818$ Found 367.0821$]$

$\mathbf{2 \cdot 1 \cdot 2}$ 試薬の調製と標準定量操作 Spm 溶液は, Spm (Sigma 製) を精秤し, 精製水で希釈して全量 $100 \mathrm{~mL}$ の $1.0 \times 10^{-2} \mathrm{M}$ 溶液とし，適宜希採して用いた。

$\mathrm{Co}(\mathrm{II})$ 溶液は, $\mathrm{Co}(\mathrm{II})$ 標準液 (和光純薬工業製) の一定 量を精秤し, 水を加え全量 $100 \mathrm{~mL}$ の $1.0 \times 10^{-3} \mathrm{M} \mathrm{Co}$ (II) 溶 液として用いた．また，他の金属溶液も同様に原子吸光用
標準液（和光純薬工業製）を用いて調製した。 キサンテン 系色素のバニリルフルオロン $(\mathrm{VF}), o$-スルホフェニルフ ルオロン $(\mathrm{SPF}), o$-カルボキシフェニルフルオロン (OCPF) は, 文献記載 ${ }^{17)}$ の方法を参考に合成し, 特級メ夕 ノール（ナカライテスク製）を加え $1.0 \times 10^{-3} \mathrm{M}$ 溶液とし た。界面活性剤溶液は，陽イオン界面活性剤として塩化ス テアリルトリメチルアンモニウム（STAC，東京化成工業 製)，臭化セチルトリメチルアンモニウム $(\mathrm{CTAB})$ ，塩化 セチルピリジニウム (CPC), 塩化テトラデシルジメチルベ ンジルアンモニウム (ゼフィラミン, Zep), 除イオン性 [ドデシル硫酸ナトリウム (SDS), ジ-2-エチルヘキシルコ ハク酸ナトリウム (AOT), 両性 [スワノール AM 301], 非 イオン性 [ポリビニルアルコール (PVA), ポリ $(N$-ビニル ピロリドン） \{PVP（K30)\}，ポリオキシエチレンソルビ夕 ンモノオレート（Tween 80)，ポリエチレングリコールモ ノ-p-オクチルフェニルエーテル（Triton X-100)] 界面活 性剂を用い, 1.0 \% 界面活性剂水溶液を調製した。緩衝液 は, ホウ砂（ナカライテスク製）水溶液を調製し, $\mathrm{pH} 9.2$ の $0.05 \mathrm{M}$ ホウ砂緩衝液として用いた.

その他の試薬は市販特級品を精製せず，そのまま用い た.また，本実験ではミリポア製 Academic A 10 型 Milli Q による精製水を使用した。

標準定量操作は, $10 \mathrm{~mL}$ のメスフラスコに, $1.0 \% \mathrm{STAC}$ 溶液 $1.0 \mathrm{~mL}, 0.05 \mathrm{M}$ ホウ砂溶液 $2.0 \mathrm{~mL}(\mathrm{pH} 9.2), 1.0 \times$ $10^{-3} \mathrm{M} \mathrm{VF}$ 溶液 $0.5 \mathrm{~mL}, 1.0 \times 10^{-3} \mathrm{M} \mathrm{Co}(\mathrm{II})$ 溶液 $0.5 \mathrm{~mL}$, 及 びSpm 含有液を加え, 次いで水で全量 $10 \mathrm{~mL} に し$, サン プル液とした. 別にSpmのみを含まず同様にして得た試薬 ブランク液と共に, $60{ }^{\circ} \mathrm{C}$ で 25 分加温後 5 分水冷し, 試薬 ブランク液を対照にサンプル液の $615 \mathrm{~nm}$ での吸光度を室 温で測定し, あらかじめ作成した検量線により Spm 量を求 めた.

\section{$2 \cdot 2$ 装 置}

吸収スペクトル及び吸光度の測定では，島津製 UV-1700 型分光光度計を用い，セルは層長 $10 \mathrm{~mm}$ の石英セルを使 用した。

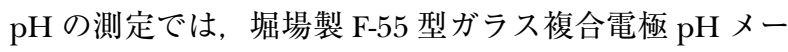
ターを使用した。

\section{3 結果及び考察}

\section{$3 \cdot 1$ 定量条件の検討}

$3 \cdot 1 \cdot 1$ 呈色反応の予備的検討 陽イオン性界面活性 剂共存下, 使用する色素及び金属イオンの組み合わせの検 討を行った. 有機試薬としてキサンテン系色素のVF, SPF, OCPF を, 金属イオンとしてコバルト(II) $\{\mathrm{Co}(\mathrm{II})\}$, マン ガン(II) $\{\mathrm{Mn}(\mathrm{II})\}$, 亜鉛(II) $\{\mathrm{Zn}(\mathrm{II})\}$, ニッケル(II) $\{\mathrm{Ni}(\mathrm{II})\}$ ，カドミウム(II) $\{\mathrm{Cd}(\mathrm{II})\}$ を用いた。 その結果, 


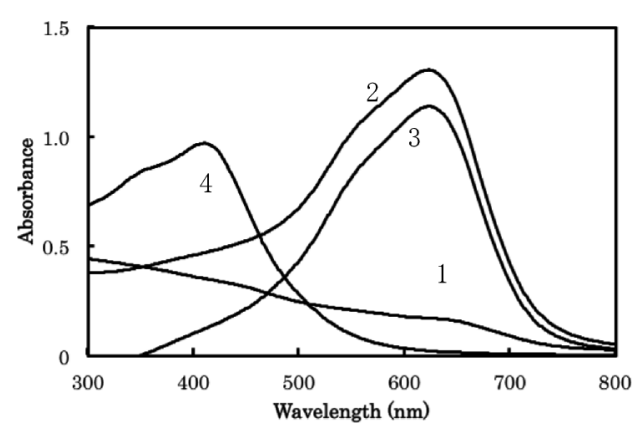

Fig. 2 Absorption spectra

Spm, $5.0 \times 10^{-6} \mathrm{M}\left(1.0 \mu \mathrm{g} \mathrm{mL} \mathrm{m}^{-1}\right) ; \mathrm{Co}(\mathrm{II}), 5.0 \times 10^{-5} \mathrm{M}$; $\mathrm{VF}, 5.0 \times 10^{-5} \mathrm{M}$; STAC, $0.1 \%$; pH, 9.2; Reference, water; Curve 1, VF-Co(II) solution; Curve 2, VF-Co(II)Spm solution; Curve 3, Curve 2 minus Curve 1; Curve 4; VF/VF -Spm solution.

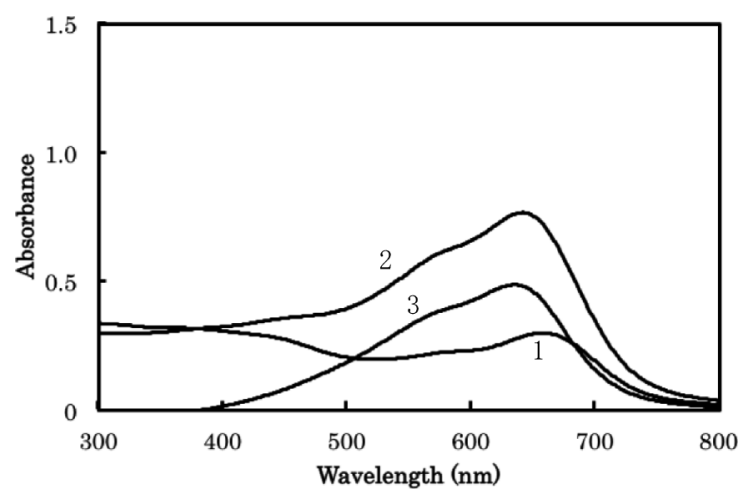

Fig. 3 Absorption spectra

Spm, $5.0 \times 10^{-6} \mathrm{M}\left(1.0 \mu \mathrm{g} \mathrm{mL} \mathrm{m}^{-1}\right) ; \mathrm{Co}(\mathrm{II}), 5.0 \times 10^{-5} \mathrm{M}$; SPF, $5.0 \times 10^{-5} \mathrm{M}$; STAC, $0.1 \%$; pH, 9.2; Reference, water; Curve 1, SPF-Co(II) solution; Curve 2, SPF -Co(II)-Spm solution; Curve 3, Curve 2 minus Curve 1.

Fig. 2 より, VF の吸収スペクトルが Co(II) の有無で変化し た（Curve 1,4)。また, [Co(II)-VF] の二元錯体の吸収スペ クトル（Curve 1）に Spm を加えると, 吸収スペクトルの 形状が顕著に変化した (Curve 2). さらに, 色素単独の場 合（Curve 4）と色素にSpm を加えた際の吸収スペクトル （Curve 4）の形状が完全に一致した. これらのことから, $[\mathrm{Co}(\mathrm{II})-\mathrm{VF}-\mathrm{Spm}]$ の三元錯体形成が示唆された. 有機試薬 として SPF や OCEP を用いた際も同様に, [Co(II)- 有機試 薬 $-\mathrm{Spm}$ ] の三元錯体が形成されることが示唆された (Fig. 3, 4). 金属試薬として Mn(II) を使用した際には, Spm の有無による吸収スペクトルの変化は極僅かなもの であった（Fig. 5). Zn(II)を用いた際にも Mn(II)の場合 と同様に Spm の有無による吸収スペクトルの形状に変化 が, 認められなかった (Fig. 6). Table 1 及び 2 に三元錯体 形成時の吸光度変化と差スペクトルの極大吸収波長を示 す. 吸光度変化が最も大きな值を示したことから, 有機試

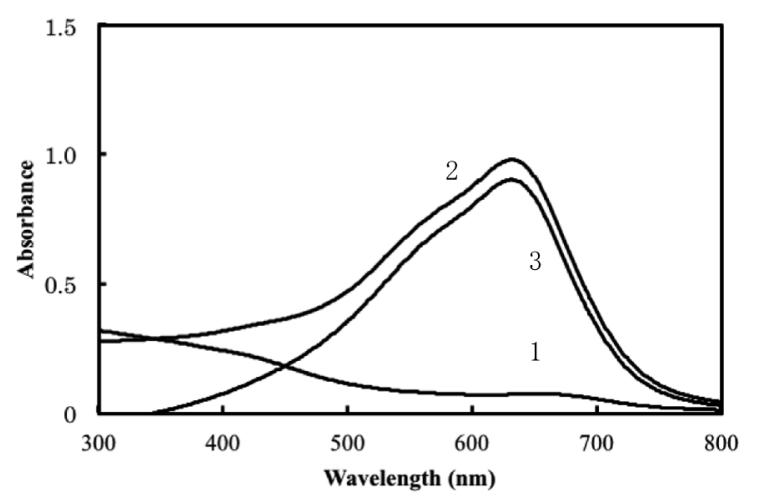

Fig. 4 Absorption spectra

Spm, $5.0 \times 10^{-6} \mathrm{M}\left(1.0 \mu \mathrm{g} \mathrm{mL} \mathrm{m}^{-1}\right) ; \mathrm{Co}(\mathrm{II}), 5.0 \times 10^{-5} \mathrm{M}$; OCPF, $5.0 \times 10^{-5} \mathrm{M}$; STAC, $0.1 \%$; pH, 9.2; Reference, water; Curve 1, OCPF -Co(II) solution; Curve 2, OCPF -Co(II)-Spm solution; Curve 3, Curve 2 minus Curve 1.

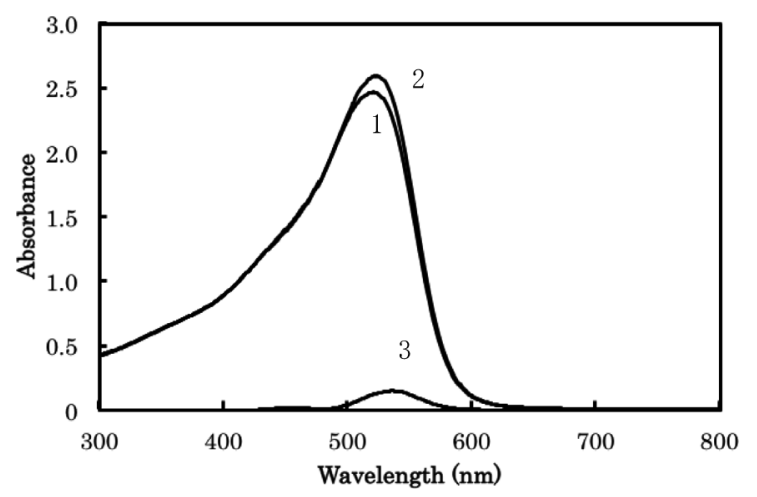

Fig. 5 Absorption spectra

Spm, $5.0 \times 10^{-6} \mathrm{M}\left(1.0 \mu \mathrm{g} \mathrm{mL} \mathrm{m}^{-1}\right) ; \mathrm{Mn}(\mathrm{II}), 5.0 \times 10^{-5} \mathrm{M}$; $\mathrm{VF}, 5.0 \times 10^{-5} \mathrm{M}$; STAC, $0.1 \%$; pH, 9.2; Reference, water; Curve 1, VF-Mn(II) solution; Curve 2, VFMn(II)-Spm solution; Curve 3, Curve 2 minus Curve 1.

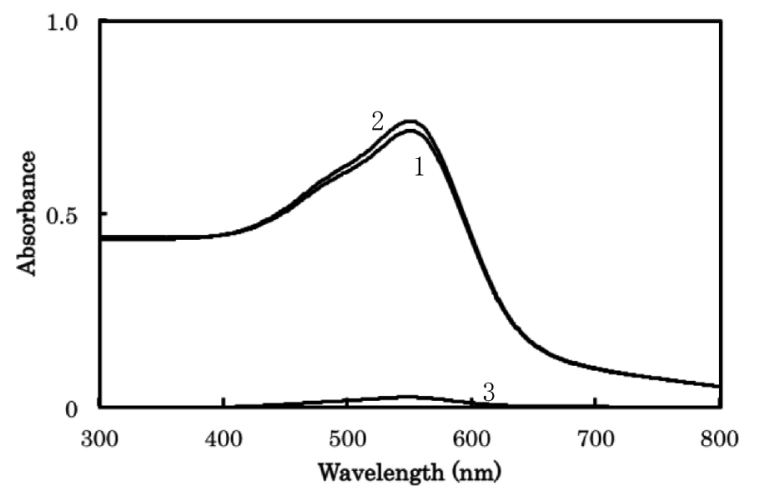

Fig. 6 Absorption spectra

Spm, $5.0 \times 10^{-6} \mathrm{M}\left(1.0 \mu \mathrm{g} \mathrm{mL} \mathrm{m}^{-1}\right) ; \mathrm{Zn}(\mathrm{II}), 5.0 \times 10^{-5} \mathrm{M}$; $\mathrm{VF}, 5.0 \times 10^{-5} \mathrm{M}$; STAC, $0.1 \%$; pH, 9.2; Reference, water; Curve 1, VF- Zn(II) solution; Curve 2, VFZn(II)-Spm solution; Curve 3, Curve 2 minus Curve 1. 
Table 1 Color reaction between Metal-VF complex and Spm

\begin{tabular}{llc}
\hline Metal ion & $\Delta$ abs. & $\lambda \max$ \\
\hline Co(II) & 1.12 & 615 \\
Ni(II) & 0.215 & 615 \\
Cd(II) & 0.19 & 615 \\
Zn(II) & 0.144 & 567 \\
Mn(II) & 0.025 & 573 \\
\hline
\end{tabular}

Spm, $5.0 \times 10^{-6} \mathrm{M}\left(1.0 \mu \mathrm{g} \mathrm{mL} \mathrm{L}^{-1}\right)$; Metal ion, $5.0 \times 10^{-5} \mathrm{M}$; VF, $5.0 \times 10^{-5} \mathrm{M}$; STAC, $0.1 \%$; pH 9.2; Reference, reagent blank solution.

薬としてVFを，金属として Co(II) を用いることで最も高 感度にSpm を定量できることが示唆された. また, 呈色体 の差スペクトルにおける極大吸収波長がもっとも長波長で あった。

$\mathbf{3} \cdot \mathbf{1} \cdot \mathbf{2}$ 液性及び緩衝液の検討本 $[\mathrm{Spm}-\mathrm{Co}(\mathrm{II})-\mathrm{VF}]$ 呈色錯体生成時における液性の影響を検討したところ, 塩 基性域において, 本反応は顕著な呈色差を示し, 反応速度 においても良好であった，次に，この液性域に緩衝能を有 する $0.05 \mathrm{M}$ ホウ砂系, $0.1 \mathrm{M}$ トリス/塩酸, $0.1 \mathrm{M}$ 炭酸水 素ナトリウム/炭酸ナトリウム, $0.2 \mathrm{M}$ アンモニア/塩化ア ンモニウム緩衝液を用いて比較検討した. その結果, $0.1 \mathrm{M}$ トリス/塩酸, $0.1 \mathrm{M}$ 炭酸水素ナトリウム/炭酸ナトリウ

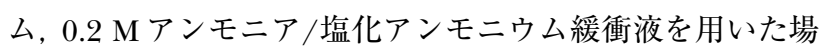
合, いづれも測定波長における試薬ブランクの吸光度が, 増大する傾向にあり, 大きな吸光度差を認めることができ なかった. $0.05 \mathrm{M}$ ホウ砂系緩衝液を用い, 最終液性を $\mathrm{pH}$ 9.0 〜 9.4 とするとき, 一定で最大の吸光度差を得ることを 認めたので, $0.05 \mathrm{M}$ ホウ砂溶液 ( $\mathrm{pH}$ 9.2) を全量 $10 \mathrm{~mL}$ に 対して $2.0 \mathrm{~mL}$ 用いることとした.

$3 \cdot 1 \cdot 3$ 界面活性剂の検討 [被分析物質一金属-有機 試薬］錯体は, 一般にかさの高い錯体が生成し, 沈殿する 場合多い. 生成する錯体の可溶化, 感度の上昇などを目的 として, 分散剤として用いる種々の界面活性剤の効果を検 討した. 本反応系の分散剂として，陽イオン性 [STAC, CTAB, CPC, 塩化テトラデシルジメチルベンジルアンモニ ウム (ゼフィラミン, Zep)], 陰イオン性 [SDS, AOT], 両 性 [スワノール AM 301], 非イオン性 [PVA, PVP（K30）, Tween 80, ポリエチレングリコールモノ-p-オクチルフェ ニルエーテル (Triton X-100) ] 界面活性剤を用い, その種 類と添加量を検討した。 その結果, 陽イオン性の STACの $1.0 \%$ 溶液を $0.7 \sim 1.2 \mathrm{~mL}$ 添加すると三元錯体が可溶化 し, 錯体形成前後で最も大きな吸光度変化が認められた. 一方, 界面活性剤なしでは, 三元錯体は沈殿した. そのた め, $1.0 \%$ STAC 溶液を全量 10 に対して $1.0 \mathrm{~mL}$ 用いるこ ととした.

$\mathbf{3} \cdot \mathbf{1} \cdot \mathbf{4}$ VF 及び Co(II) 濃度の影響 $\quad \operatorname{Spm}\left(1.0 \times 10^{-6} \mathrm{M}\right)$
Table 2 Color reaction between Co(II)-dye complex and Spm

\begin{tabular}{ccc}
\hline Dye & $\Delta$ abs. & $\lambda \max$ \\
\hline VF & 1.120 & 615 \\
OCPF & 0.900 & 615 \\
SPF & 0.485 & 615 \\
\hline
\end{tabular}

Spm, $5.0 \times 10^{-6} \mathrm{M}\left(1.0 \mu \mathrm{g} \mathrm{mL} \mathrm{L}^{-1}\right) ; \mathrm{Co}(\mathrm{II}), 5.0 \times 10^{-5} \mathrm{M} ;$ Dye, $5.0 \times 10^{-5} \mathrm{M}$; STAC, $0.1 \%$; pH 9.2; Reference, reagent blank solution.

及び $\mathrm{Co}(\mathrm{II})\left(5.0 \times 10^{-5} \mathrm{M}\right)$ の一定濃度に対して, VF の最 適濃度を検討したところ, $5.0 \times 10^{-5} \mathrm{M} \mathrm{VF}$ 溶液を用いると き, $615 \mathrm{~nm}$ において最大の吸光度差を得ることができた. また, VF を最終濃度 $5.0 \times 10^{-5} \mathrm{M}$ としたときの Co(II) 量を $5.0 \times 10^{-5} \sim 1.5 \times 10^{-4} \mathrm{M}$ で検討したところ, $\mathrm{Co}(\mathrm{II})$ と VF の モル比を $1: 1$ で加えるとき, 最大でほぼ一定の吸光度を得 ることができた．したがって，色素のVF及び金属イオン の $\mathrm{Co}(\mathrm{II})$ の最終濃度として，それぞれ $5.0 \times 10^{-5} \mathrm{M}$ とする こととした.

$3 \cdot 1 \cdot 5$ 反応温度と呈色体の安定性本反応におい て, 反応の加速を目的として $50 \sim 70{ }^{\circ} \mathrm{C}$ の反応温度及び 0

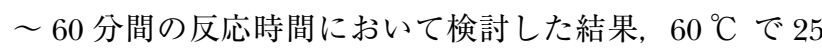
分加温反応後, 5 分間水冷するとき最も高い吸光度差が得 られ，その後も室温で 60 分間ほぼ一定であり安定であっ た。

\section{$3 \cdot 2$ 吸収スペクトル及び検量線}

本アッセイ法により, Spm 各濃度における $615 \mathrm{~nm}$ での 吸光度差をもとに検量線を作成したところ，0.04〜 $1.0 \mu \mathrm{g}$ $\mathrm{mL}^{-1}$ の Spm 濃度範囲において良好な直線を得ることがで き，検出限界は $0.01 \mu \mathrm{g} \mathrm{mL} \mathrm{L}^{-1}$ であった。

本操作による定量感度は, みかけのモル吸光係数 $\varepsilon=$ $2.2 \times 10^{5} \mathrm{~L} \mathrm{~mol}^{-1} \mathrm{~cm}^{-1}$ であり, 5 回繰り返しにおける再現精 度 RSD は Spm $0.35 \mu \mathrm{g} \mathrm{mL} \mathrm{m}^{-1}$ において $2.5 \%$ であった. 非 侵襲性試料としての尿中スペルミンを定量することは重要 である. Spm は体内で代謝されることにより, 尿中でアセ チル化体として存在している. 通常, このアセチルスペル ミンが測定対象となるが，スペルミンそのものも微量に含 まれていることから，総スペルミンとして測定することが 重要であると考えられる，本アッセイ法では，OCPF マン ガン法 ${ }^{15)}$ に従ってケン化の前処理をすることによりスペル ミンのアセチル化体を定量することが可能であった。

\section{$3 \cdot 3$ 共存物質の影響}

本標準定量操作における共存物質の影響を, Spmに対し てモル比で $1 \sim 100$ 倍の範囲で添加して検討した. 以上の 
Table 3 Effect of foreign substances

\begin{tabular}{lccr}
\hline Substance & $\begin{array}{c}\text { Added } \\
\mu \mathrm{g} \mathrm{mL} \mathrm{mL}^{-1}\end{array}$ & $\begin{array}{c}\text { Absorbance } \\
\text { at } 615 \mathrm{~nm}\end{array}$ & $\begin{array}{c}\text { Recovery, } \\
\%\end{array}$ \\
\hline None & - & 0.311 & 100.0 \\
$\mathrm{Ca}(\mathrm{II})$ & 4.0 & 0.297 & 95.4 \\
$\mathrm{Fe}(\mathrm{II})$ & $5.6 \times 10^{-2}$ & 0.352 & 113.0 \\
$\mathrm{Zn}(\mathrm{II})$ & $6.5 \times 10^{-2}$ & 0.311 & 100.0 \\
$\mathrm{Cu}(\mathrm{II})$ & $6.4 \times 10^{-2}$ & 0.194 & 62.2 \\
$\mathrm{NaCl}$ & 5.8 & 0.311 & 100.0 \\
$\mathrm{KNO}{ }_{3}$ & 10.1 & 0.311 & 100.0 \\
$\mathrm{KBr}$ & 11.9 & 0.311 & 100.0 \\
Na ${ }_{2} \mathrm{HPO}{ }_{4}$ & $1.4 \times 10^{-2}$ & 0.311 & 100.0 \\
Urea & 6.0 & 0.311 & 100.0 \\
$\mathrm{Creatinine}$ & 11.3 & 0.311 & 100.0 \\
Glucose & 18.0 & 0.311 & 100.0 \\
Caffeine & 19.4 & 0.298 & 95.7 \\
Thiamine & $2.7 \times 10^{-1}$ & 0.311 & 100.0 \\
Oxalate & 9.0 & 0.300 & 96.5 \\
Citrate & 3.8 & 0.283 & 90.9 \\
Ascorbate & $1.8 \times 10^{-2}$ & 0.341 & 110.0 \\
HSA & 5.0 & 0.311 & 100.0 \\
\hline
\end{tabular}

Spm, $1.0 \times 10^{-6} \mathrm{M}\left(0.2 \mu \mathrm{g} \mathrm{mL} \mathrm{m}^{-1}\right) ; \mathrm{Co}(\mathrm{II}), 5.0 \times 10^{-5} \mathrm{M} ; \mathrm{VF}$, $5.0 \times 10^{-5} \mathrm{M}$; STAC, $0.1 \%$; pH 9.2; Reference, reagent blank solution.

結果を Table 3 に示す.

金属イオンのうち, $\mathrm{Fe}(\mathrm{II})$ においては等モル量において 正の誤差を, $\mathrm{Cu}(\mathrm{II})$ においては等モル量において負の誤差 を生じた. 尿中には Fe(II) や $\mathrm{Cu}(\mathrm{II})$ がそれぞれ $0.1 〜 0.2$ $\mathrm{mg} \mathrm{day}{ }^{-1}, 4.0 \sim 33 \mu \mathrm{g} \mathrm{day}{ }^{-1}$, 存在することが知られてい る. そのため, 尿試料を対象として, 本法でスペルミンを 定量する際に, $\mathrm{Fe}(\mathrm{II})$ や $\mathrm{Cu}(\mathrm{II})$ の影響は極僅かなものであ ると考えられる.

更に生体中に存在する有機酸や有機化合物の共存につい て検討したところ，アスコルビン酸においては等量におい て正の誤差が生じ, 尿中測定には, 適切な酸化剂による処 理等が必要である可能性が示唆された。 また, クエン酸に おいては, Spmに対して 20 倍量添加で負の誤差を生じた ので，適量の金属添加などが必要であると考えられたが, 尿素, クレアチニン, グルコース等多くの物質では共存に よる影響は見られなかった。

\section{4 結 語}

$0.05 \mathrm{M}$ ホウ砂緩衝液を用いる塩基性域において, 陽イオ ン界面活性剂の STAC 共存下, VF を用いる簡便, 高感度な Spm の吸光光度定量法を開発することができた. 本法にお いて, Spm 定量時, $0.04 \sim 1.0 \mu \mathrm{g} \mathrm{mL} \mathrm{m}^{-1}$ の濃度範囲で Beer の法則が成立し, 定量感度及び精度はそれぞれ $\varepsilon=2.2 \times 10^{5}$ $\mathrm{L} \mathrm{mol}^{-1} \mathrm{~cm}^{-1}$ 及び $\mathrm{RSD}=2.5 \%(n=5)$ であり, OCPF マン ガン法 ${ }^{15)}$ の約 2 倍の感度を示した. 尿中及び体液中のポリ アミン定量への本法の応用を含め, 呈色錯体の組成につい ては今後, より詳細に検討する必要がある.

\section{文献}

1) 五十嵐一衛: “神秘の生命物質一ポリアミン”, (1993), (共立出版).

2) 永津俊治：“生理活性アミンと生体防御 (上・下)”, (1981), (共立出版).

3) N. Seiler : J. Chromatogr, 379, 157 (1986).

4) C. M. Legua, P. C. Falco, A. S. Cabeza, M. P. Pons : Analyst, 124, 477 (1999).

5) K. Maruta, R. Teradaira, N. Watanabe, T. Nagatsu, M. Asano, K. Yamamoto, T. Matsumoto, Y. Shionoya, K. Fujita : Clin. Chem., 35, 1694 (1989).

6) K. Shinpo, K. Fujita, K. Maruta, R. Teradaira, T. Nagatsu : Clin. Chem. Acta, 131, 143 (1983).

7) N. Seiler, N. Frank, F. N. Bolkenius, B. Knodgen : Biochem. J., 225, 219 (1985).

8) C. Loser, U. Wunderlich, U. R. Fosch : J. Chromatogr., 430, 249 (1988).

9) T. Weiss, G. Bernhardt, A. Buschauer, K. W. Jauch, H. Zirngibl : Anal. Biochem., 247, 294 (1997).

10) K. Fujiwara, H. Kanetake, K. Furukawa, Y. Masuyama, G. Bai, H. Tanimori, T. Kitagawa : J. Biochem., 118, 1211 (1995).

11) M. D. Denton, H. S. Glazer, D. C. Zellner, F. G. Smith : Clin. Chem., 19, 904 (1973).

12) M. Niitsu, K. Samejima, S. Matsuzaki, K. Hamana : J. Chromatogr., 641, 115 (1993).

13) D. C. Weatherburn : Aust. J. Chem., 36, 433 (1983).

14) L. Lomozik, R. Jastrzab : J. Inorg. Biochem., 93, 132 (2003).

15) K. Miyachi, K. Moriyama, T. Yamaguchi, H. Tominaga, S. Kamino, Y. Fujita : Anal. Sci., 23, 1103 (2007).

16) 藤田芳一：ぶんせき (Bunseki), 2008, 596.

17) H. Sano : Bull. Chem. Soc.Jpn., 31, 974 (1958).

18 ) 金井正光 : 臨床検査法提要, 第 32 版, (2005), (金 原出版). 


\title{
Spectrophotometric Detenmination of Spermine with Vanillylfluorone and Cobalt(II)
}

\author{
Showa Kashiwagi ${ }^{1}$, Momoka Matsushita ${ }^{1}$, Kanako Mirachi ${ }^{1}$, Mamiko Asano ${ }^{1}$, \\ Mihoyo Fujitake ${ }^{1}$, Takako Yamaguchi ${ }^{* 1}$, Hitoshi Matsumura ${ }^{1}$ and Yoshikazu Fujita ${ }^{1,2,3}$ \\ * E-mail : yamaguti@gly.oups.ac.jp
}

${ }^{1}$ Osaka University of Pharmaceutical Sciences, 4-20-1, Nasahara, Takatsuki-shi, Osaka 569-1094

${ }^{2}$ Osaka Shin-Ai Jogakuin, 2-7-30, Furuichi, Joutou-ku Osaka-shi, Osaka 536-8585

${ }^{3}$ Saera Pharmacy, Honmachidai2 Bld.3F, 2-2-5. Honmachi, Chuo-ku Osaka-shi, Osaka 541-0053

(Received May 16, 2016; Accepted September 12, 2016)

\begin{abstract}
A novel spectrophotometric method was established for the determination of spermine based on color complex formation among vanillylfluorone, cobalt(II) and spermine in the presence of stearyltrimethylammonium chloride. In the determination of spermine, Beer's low was obeyed in the range of $0.04-1.0 \mu \mathrm{g} \mathrm{mL}^{-1}$. The effective molar absorptivity at $615 \mathrm{~nm}$ and the relative standard deviation were $2.2 \times 10^{5} \mathrm{~L} \mathrm{~mol}^{-1} \mathrm{~cm}^{-1}$ and $2.5 \%(n=5)$, respectively.
\end{abstract}

Keywords: spectrophotometry; vanillylfluorone; cobalt(II); spermine. 